\title{
Relationship Between Serum Levels of Arsenic, Cadmium, and Mercury and Body Mass Index and Fasting Plasma Glucose in a Mexican Adult Population
}

\author{
Héctor Hernández-Mendoza ${ }^{1,2}$ (1) - Héctor Edmundo Álvarez-Loredo ${ }^{3}$ (1) - Elizabeth Teresita Romero-Guzmán ${ }^{4}$ (D) \\ Darío Gaytán-Hernández ${ }^{5}$ (D) . Consuelo Chang-Rueda ${ }^{6}$ (D) Israel Martínez-Navarro ${ }^{3}$ (D) . \\ Bertha Irene Juárez-Flores ${ }^{1}$ (D) . María Judith Rios-Lugo ${ }^{3,5}$ (D)
}

Received: 2 November 2021 / Accepted: 20 December 2021 / Published online: 31 January 2022

(c) The Author(s), under exclusive licence to Springer Science+Business Media, LLC, part of Springer Nature 2021

\begin{abstract}
In Mexico, few studies have analyzed the associations between toxic elements and metabolic diseases. In the present study, we analyzed the associations between serum arsenic (As), cadmium $(\mathrm{Cd})$, and mercury $(\mathrm{Hg})$ levels and body mass index (BMI) and fasting plasma glucose (FPG) in a Mexican adult population. Anthropometric data corresponding to 86 Mexican healthy adults (59 females and 27 men) were analyzed. FPG was analyzed by an enzymatic colorimetric method, and serum As, Cd, and $\mathrm{Hg}$ levels were analyzed by inductively coupled plasma-mass spectrometry (ICP-MS). The data show that the median serum $\mathrm{As}, \mathrm{Cd}$, and $\mathrm{Hg}$ levels were relatively higher in females (As $=1.78 \mathrm{ng} \mathrm{mL}^{-1}, \mathrm{Cd}=1.00 \mathrm{ng} \mathrm{mL}^{-1}, \mathrm{Hg}=0.96 \mathrm{ng} \mathrm{mL}^{-1}$ ) than those in males $\left(\mathrm{As}=1.22 \mathrm{ng} \mathrm{mL}{ }^{-1}, \mathrm{Cd}=0.91 \mathrm{ng} \mathrm{mL}^{-1}, \mathrm{Hg}=0.95 \mathrm{ng} \mathrm{mL}^{-1}\right.$ ). However, these differences were not statistically significant $(p \geq 0.097)$. We also found that the median level of As significantly increased with an increase in the body weight categories (normal weight $=1.08$; overweight $=1.50$; obesity $=2.75 ; p<0.001$ ). In addition, a positive association between serum As levels and FPG before and after adjustment for BMI was demonstrated $\left(\mathrm{Rho}_{\text {Unadjusted }}=0.012\right.$; $\left(\mathrm{RhoA}_{\mathrm{djusted}}=0.243, p=0.032\right)$. Serum As levels are positively associated with BMI and FPG in the adult population of Mexico. Nevertheless, these results need to be replicated and confirmed with a larger sample size.
\end{abstract}

Keywords Toxic elements (As $\cdot \mathrm{Hg} \cdot$ And Cd) $\cdot$ Serum $\cdot$ Body mass index $\cdot$ Glucose $\cdot$ Mexican adult population

\section{Introduction}

Body mass index (BMI) has been used to assess the body weight categories of an individual and can be classified into normal weight $(\mathrm{NW})$, overweight $(\mathrm{OW})$, and obesity $(\mathrm{OB})$

Héctor Hernández-Mendoza

hector.mendoza@uaslp.mx; judith.rios@uaslp.mx

María Judith Rios-Lugo

hector.mendoza@uaslp.mx; judith.rios@uaslp.mx

1 Instituto de Investigación de Zonas Desérticas, Universidad Autónoma de San Luis Potosí, Altair 200,

C.P: 78377 San Luis Potosí, S.L.P., México

2 Universidad del Centro de México, Capitán Caldera 75, C.P: 78250 San Luis Potosí, S.L.P., México

3 Centro de Investigación en Ciencias de Salud y Biomedicina, Sección de Medicina Molecular y Traslacional, Universidad Autónoma de San Luis Potosí, Avda Sierra Leona 550, C.P: 78210 San Luis Potosí, S.L.P., México
$[1,2]$. Moreover, obesity is defined as an excessive accumulation of fat in the body and is often subdivided into three classes (1 (BMI of 30 to <35), 2 (BMI of 35 to <40), and 3 (BMI of 40 or higher)). Furthermore, the World Health Organization (WHO) report shows worrying data on the

4 Departamento de Química, Gerencia de Ciencias Básicas, Dirección de Investigación Científica, Carretera México-Toluca S/N, C.P: 52750 La Marquesa Ocoyoacác, México

5 Facultad de Enfermería Y Nutrición, Unidad de Posgrado, Universidad Autónoma de San Luis Potosí, Avda. Niño Artillero 130, C.P: 78210 San Luis Potosí, S.L.P., México

6 Facultad de Ciencias Químicas, Universidad Autónoma de Chiapas, Campus IV Carretera a Puerto Madero Km 1.5, C.P: 30580 Tapachula, Chiapas, México 
increase in OW and OB [3]; their prevalence has increased threefold since 1975 . Today, the estimated number of individuals living with $\mathrm{OW}$ and $\mathrm{OB}$ exceeds 2 billion.

$\mathrm{OW}$ and $\mathrm{OB}$ are considered reversible diseases if they are controlled early enough. Nevertheless, OW and OB contribute to the development of other metabolic diseases that are not reversible, such as diabetes mellitus, metabolic syndrome, dyslipidemia, and cardiovascular diseases [4-8]. Recently, OW and OB have been associated with increased severity of disease and mortality in the adult population with COVID-19 disease [9-11].

According to the Mexican National Health and Nutrition Survey (2016), the prevalence of OW and OB in children and adults is higher in México than that in other countries with Latin American populations [12]. In addition, in 2017, the Organization for Economic Cooperation and Development (OECD) reported the prevalence of OW and $\mathrm{OB}$ worldwide, and Mexico had the highest prevalence of obesity in the population aged 15-74 years [13].

Today, human health risks are more evident by exposure to toxic elements, and billions of people worldwide have been exposed to arsenic (As), mercury ( $\mathrm{Hg}$ ), and cadmium (Cd) in very small amounts by the intake of food, water, and air. In addition, the WHO reported that these toxic elements, including lead $(\mathrm{Pb})$, are among the top ten chemicals of public health concern [14]. Furthermore, recent evidence has shown that $\mathrm{As}, \mathrm{Hg}$, and $\mathrm{Cd}$ are associated with the development of metabolic diseases, especially diseases that have been associated with obesity [15-20]. The exact mechanisms of $\mathrm{As}, \mathrm{Hg}$, or $\mathrm{Cd}$ in the body are not completely understood; however, these chemicals have been associated with oxidative stress, inflammation, insulin resistance, and adipokine expression in humans [21-26]. Hg induces oxidative stress, inflammation, and insulin resistance, and it is associated with hypertension and dyslipidemia [25-27]. Cd is associated with endocrine disruption, and its mechanisms of toxicity include oxidative stress, inflammation, and interference with trace element metabolism of $\mathrm{Zn}, \mathrm{Cu}$, and $\mathrm{Cr}$ [23, 28]. Moreover, exposure to As has been associated with the pathophysiology of obesity and diabetes mellitus due to free radical formation, which contributes to inflammation and oxidative stress in these diseases [21,22]. Fasting plasma glucose (FPG) is a test used for the diagnosis of diabetes [29]. FPG is a risk indicator for obesity, and in turn, it has been associated with diabetes mellitus [30] and metabolic syndrome [31]. $\mathrm{Hg}$, As, and Cd exposure could alter glucose regulation.

In Mexico, few studies have been carried out to evaluate the association of toxic elements with metabolic diseases. For this reason, the present work evaluates the serum $\mathrm{Cd}$, $\mathrm{Hg}$, and As levels and their association with BMI, as an obesity marker, and FPG in a Mexican adult population.

\section{Materials and Methods}

\section{Study Characteristics}

In this cross-sectional study, we included a total of 86 Mexican adult students (59 females and 27 men, between 19 and 24 years old, with a median age of 20.3 years) with normal glucose tolerance (NGT) from the Faculty of Nursing and Nutrition of the University Autonomous of San Luis Potosí in San Luis Potosí, Mexico. Adults with FPG $\leq 126 \mathrm{mg} / \mathrm{dL}$ were considered to have NGT according to the 2003 American Diabetes Association criteria [32]. By self-report, adults with diseases that could confound the association analysis in the study, such as AIDS and/ or chronic liver/kidney disease and/or any cancer, were excluded from this study.

\section{Ethical Approval}

This work was conducted according to the ethical criteria from the Guidelines of the General Health Law on Health in Mexico and following the guidelines of the Declaration of Helsinki. The Ethics Committee of the Faculty of Nursing and Nutrition, Autonomous University of San Luis Potosí, approved the protocol with the register number 2014-092, and written consent forms were obtained from all participants.

\section{Anthropometry}

For the measurement of BMI, height and weight were determined with a portable stadiometer (Seca, Hamburg, Germany) and a bioelectrical impedance scale (SECA Model 818), respectively. BMI was calculated as the ratio of weight in kilograms and height squared in centimeters. The categories of body weight were classified into three categories: $\mathrm{BMI}<25$ was $\mathrm{NW}, \mathrm{BMI} \geq 25$ was $\mathrm{OW}$, and $\mathrm{BMI} \geq 30$ was $\mathrm{OB}$.

\section{Collection and Preparation of Serum Samples}

Serum samples were collected at the university's clinical analysis laboratory. Standardized protocols were used for serum extraction. This process is summarized in three steps. First, $5 \mathrm{~mL}$ of peripheral blood was extracted by venipuncture in a sterile vacutainer tube after $12 \mathrm{~h}$ of fasting. Second, serum was separated after blood coagulation by centrifugation at $4000 \mathrm{rpm}$ at $4{ }^{\circ} \mathrm{C}$ for $10 \mathrm{~min}$. Third, serum samples were collected with transfer pipettes and stored in Eppendorf tubes at $-80{ }^{\circ} \mathrm{C}$ until analysis. 
Samples were thawed overnight at $4{ }^{\circ} \mathrm{C}$ in a cold room. Then, $200 \mu \mathrm{L}$ from each serum sample was transferred to a 1.5-mL Eppendorf tube. Iridium (Ir) and indium (In) were added to the samples at a concentration of $10 \mathrm{ng} \mathrm{mL}^{-1}$ as internal standards, and $10 \mathrm{ng} \mathrm{mL}^{-1}$ gold $(\mathrm{Au})$ was added to avoid $\mathrm{Hg}$ losses during the treatment of the sample. In addition, $100 \mu \mathrm{L}$ of concentrated high purity $\mathrm{HNO}_{3}$ was added to each sample. Finally, the samples were homogenized and stored at room temperature.

Samples were recovered from Eppendorf tubes using micropipettes and $3 \mathrm{~mL}$ of concentrated $\mathrm{HNO}_{3}$. Samples were transferred into Teflon tubes for microwave digestion (MARS6 CEM, Matthews, North Carolina). Then, $5 \mathrm{~mL}$ concentrated $\mathrm{HNO}_{3}$ was added to the Teflon tubes. The acid digestion process consisted of a temperature increase to $180^{\circ} \mathrm{C}$ and a digestion time of $20 \mathrm{~min}$. All samples were recovered from the Teflon tubes with concentrated $\mathrm{HNO}_{3}$. Then, they were dried on plates by evaporation using a glass beaker of $50 \mathrm{~mL}$ and watch glass to prevent mass losses from projections. Samples were diluted to $10 \mathrm{~mL}$ with $2 \%$ $\mathrm{v} / \mathrm{v} \mathrm{HNO}_{3}$ concentrated for $\mathrm{Hg}$, As, and $\mathrm{Cd}$ measurement by inductively coupled plasma-mass spectrometry (ICP-MS). The Eppendorf tubes, Teflon tubes, glass beaker, and volumetric flasks were previously decontaminated. Moreover, blank samples were prepared to quantify the contribution of $\mathrm{As}, \mathrm{Hg}$, and $\mathrm{Cd}$ using concentrated $\mathrm{HNO}_{3}$ and water.
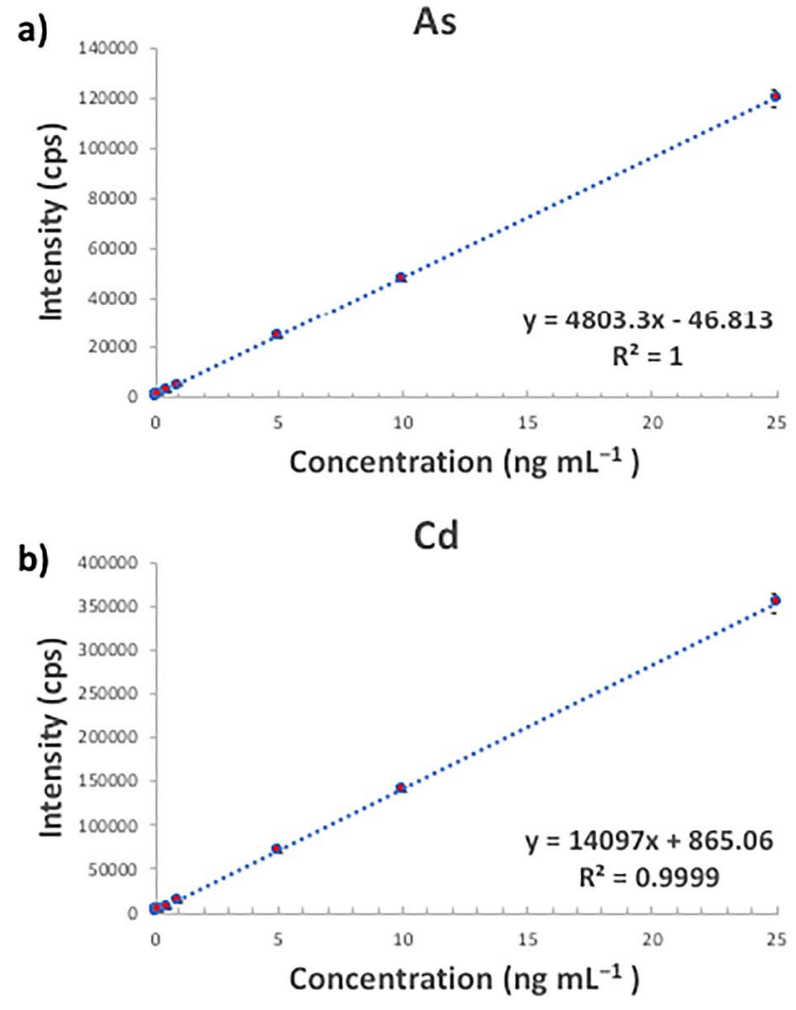

The concentrated $\mathrm{HNO}_{3}$ used in all processes was of high purity and purified by a Milestone Duopur system (Milestone Srl, Italy). Moreover, water of high purity $>18 \mathrm{M} \Omega$ $\mathrm{cm}$ was obtained from a Milli-Q ${ }^{\circledR}$ system (Millipore, México) and used for the treatment samples and external curve preparation.

\section{Quantification of $\mathrm{Hg}, \mathrm{Cd}$, and As by ICP-MS}

$\mathrm{Hg}, \mathrm{Cd}$, and As were measured by ICP-MS (iCAP from Thermo Scientific, Germany) with collision reaction cells (helium mode) and kinetic energy discrimination (KED). For mass calibration, a certified reference material (CRM) was used for ICP-MS iCAP Q/RQ. Ba, Bi, Ce, Co, In, Li, and $\mathrm{U}$ at a concentration of $1.00 \pm 0.05 \mu \mathrm{g} \mathrm{L}^{-1}$ were used (Alfa Aesar, Specpure, USA). Quantification of $\mathrm{Hg}, \mathrm{Cd}$, and As was performed using CRMs at a concentration of $1000 \pm 0.06 \mu \mathrm{g} \mathrm{mL}^{-1}$ (High Purity Standards, USA). Concentrations used for the preparation of external calibration were $0.01,0.05,0.1,0.5,1,5,10$, and $25 \mathrm{ng} \mathrm{mL}^{-1}$. Moreover, Ir, In, and Au were obtained at a concentration of $1000 \pm 0.06 \mu \mathrm{g} \mathrm{mL}^{-1}$ from High Purity Standards, USA. Finally, serum $\mathrm{Hg}, \mathrm{Cd}$, and As concentration levels were calculated by subtracting reagent blanks and the recovery percentage of Ir and In. Figure 1 shows the calibration curve and linear regression of each element. In addition, quality

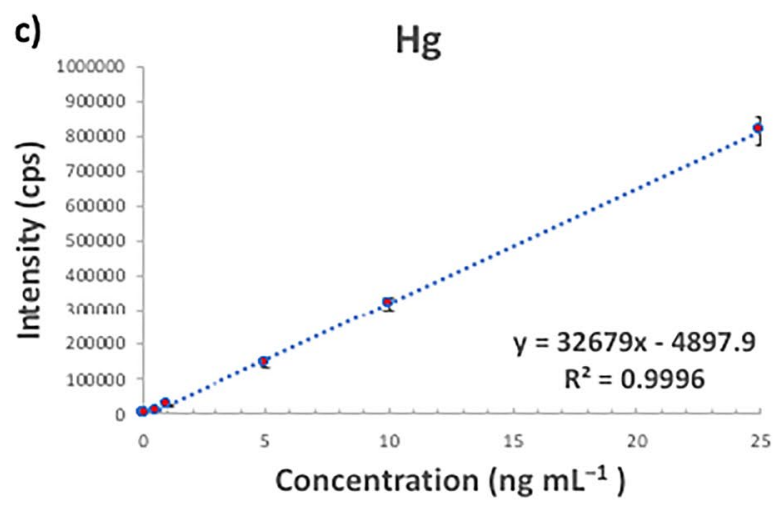

d)

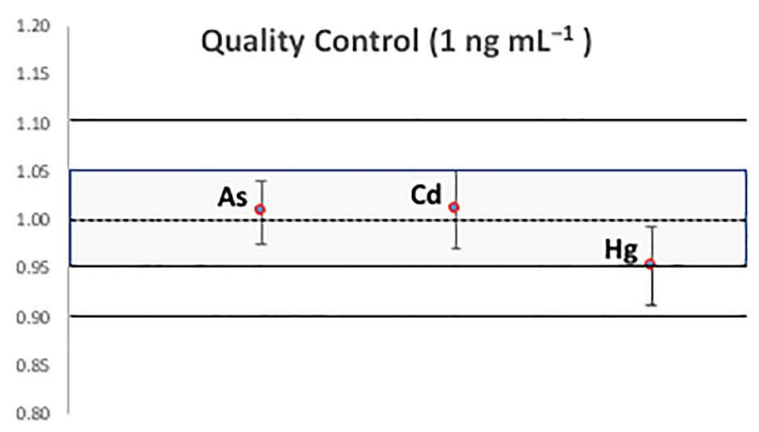

Fig. 1 Calibration curves and quality control; a) $\mathrm{As}, \mathbf{b}) \mathrm{Cd}$, c) $\mathrm{Hg}$, and d) quality control used in the analysis of serum sample $(n=7)$ 
control of $1 \mathrm{ng} \mathrm{mL}{ }^{-1}$ showed standard deviations less than $5 \%$ for $n=7$. The reagent blank intensities of $\mathrm{As}, \mathrm{Cd}$, and $\mathrm{Hg}$ in terms of count per second (cps) were $15 \pm 9 \mathrm{cps}, 139 \pm 49$ cps, and $31 \pm 15 \mathrm{cps}$, respectively. Moreover, the recovery yields of In and Ir were $89 \pm 5 \%$ and $93 \pm 3 \%$, respectively. For calculating the concentrations of $\mathrm{As}, \mathrm{Cd}$, and $\mathrm{Hg}$, only Ir was used because this had better recovery in the treatment process.

\section{Glucose Measurements}

Glucose was measured with commercially available kits from Spinreact (Glucose LQ, LIQ423) and using a Halo DB-20 UV-Vis spectrophotometer from Dynamica (UK). All determinations of glucose were performed according to the manufacturer's protocol.

\section{Statistical Analysis}

The Shapiro-Wilk test was used to determine the normality of the distribution of variables. Chi-square tests were employed to compare frequencies between study groups. The variables that did not show rich normality were normalized with rank-based inverse normal transformation (Supplementary Table 1) [33]. According to the normality of the raw data of the quantitative variables (Supplementary Table 1), Student's $t$, Mann-Whitney $U$, and Kruskal-Wallis tests were used to compare these variables between the study groups. Additionally, Spearman's rho coefficient was determined (unadjusted model), and Spearman's rank correlation analysis (with the normalized data) adjusted for age and sex was performed to evaluate the associations between $\mathrm{As}, \mathrm{Cd}$, and $\mathrm{Hg}$ and BMI and FPG. The associations between $\mathrm{As}, \mathrm{Cd}$, and $\mathrm{Hg}$ and FPG were additionally adjusted for BMI. SPSS software (version 22.0, BMI, NY, USA) was used to perform the statistical analysis, and a two-sided $p$ value $<0.05$ was considered significant.

\section{Results}

\section{General Characteristics of the Sample Study}

The general characteristics of the sample study are shown in Table 1. The variables of age and BMI were homogenous between the female and male groups $(p \geq 0.152)$. However, the mean FPG was significantly higher in males than that in females $(p=0.026)$. The median levels of serum As, $\mathrm{Cd}$, and $\mathrm{Hg}$ were relatively higher in females than those in males $(\mathrm{As}=31.46 \%, \mathrm{Cd}=9.0 \%, \mathrm{Hg}=1.04 \%)$. However, these differences were not statistically significant $(p \geq 0.097)$. Moreover, the frequency of overweight and obesity was homogeneous in the female and male groups $(p=0.726)$.
Table 1 General characteristics of total sample

\begin{tabular}{llll}
\hline Trait & $\begin{array}{l}\text { Female } \\
(\boldsymbol{N = 5 9 )}\end{array}$ & $\begin{array}{l}\text { Male } \\
(\boldsymbol{N = 2 7})\end{array}$ & $\begin{array}{l}p \text { value } \\
\text { NA }\end{array}$ \\
\hline Age (years) & $20.0(19.0-22.0)$ & $20.0(19.0-22.0)$ & 0.555 \\
BMI $\left(\mathrm{kg} / \mathrm{m}^{2}\right)$ & $27.1(24.6-29.8)$ & $26.2(23.3-27.9)$ & 0.152 \\
FPG $(\mathrm{mg} / \mathrm{dL})$ & $83.97 \pm 5.64$ & $87.30 \pm 7.63$ & $0.026^{*}$ \\
As $(\mathrm{ng} / \mathrm{mL})$ & $1.78(1.10-2.84)$ & $1.22(0.40-2.47)$ & 0.097 \\
Cd $(\mathrm{ng} / \mathrm{mL})$ & $1.00(0.80-2.01)$ & $0.91(0.55-1.70)$ & 0.282 \\
Hg $(\mathrm{ng} / \mathrm{mL})$ & $0.96(0.93-1.03)$ & $0.95(0.93-1.00)$ & 0.555 \\
Overweight $n(\%)$ & $29(49.2)$ & $14(51.9)$ & 0.726 \\
Obesity $n(\%)$ & $13(22.0)$ & $4(14.8)$ & \\
\hline
\end{tabular}

Data are expressed as mean \pm standard deviation, median (interquartile rank), and $N(\%)$. Chi-square test was used to compare frequencies, and Student's $t$ and $U$ Mann-Whitney tests were used to continue variables. Abbreviations: $N A$, not analyzed; $B M I$, body mass index; $F P G$, fasting plasma glucose; $A s$, arsenic; $C d$, cadmium; $H g$, mercury. ${ }^{*}$ Significant $p$ values $(p<0.05)$

\section{Concentration of Serum As, Cd, and $\mathrm{Hg}$ by Body Weight Categories}

The results obtained for the concentrations of serum $\mathrm{As}, \mathrm{Cd}$, and $\mathrm{Hg}$ by body weight categories are shown in Table 2. The median level of As increased with an increase in the body weight categories $(p<0.001)$. However, the median levels of $\mathrm{Cd}$ and $\mathrm{Hg}$ did not show significant differences among the body weight categories analyzed ( $p \geq 0.166$; Table 2). Figure 1 shows the calibration curve and linear regression of each element. In addition, quality control of $1 \mathrm{ng} \mathrm{mL}^{-1}$ showed standard deviations less than $5 \%$ for $n=7$. The reagent blank intensities of As, Cd, and $\mathrm{Hg}$ in terms of count per second (cps) were $15 \pm 9 \mathrm{cps}$, $139 \pm 49 \mathrm{cps}$, and $31 \pm 15 \mathrm{cps}$, respectively. Moreover, the recovery yields of In and Ir were $89 \pm 5 \%$ and $93 \pm 3 \%$, respectively. For calculating the concentrations of As, Cd, and $\mathrm{Hg}$, only Ir was used because Ir had better recovery in the treatment process.

\section{Associations Between Serum As, Cd, and Hg Levels and BMI and FPG}

Table 3 shows the associations between serum As, $\mathrm{Cd}$, and $\mathrm{Hg}$ levels and BMI and FPG before and after adjustment for age and sex. The results showed that the serum level of As was significantly associated with an increase in BMI and FPG level before and after adjustment for age and sex (BMI: $p_{\text {Unadjusted }}<0.001, p_{\text {Age and sex adjusted }}<0.001$; FPI: $p_{\text {Unadjusted }}=0.030 ; p_{\text {Age and sex adjusted }}=0.012$; Table 3 ). We then analyzed the association between serum As level and FPG additionally adjusted for BMI, and the effect was still significant $(\mathrm{Rho}=0.243, p=0.032)$. 
Table 2 Description of serum $\mathrm{As}, \mathrm{Cd}$, and $\mathrm{Hg}$ levels by nutritional categories

\begin{tabular}{lllll}
\hline Trait & $\begin{array}{l}\text { Normal weight } \\
(\boldsymbol{N = 2 6})\end{array}$ & $\begin{array}{l}\text { Overweight } \\
(\boldsymbol{N = 4 3 )}\end{array}$ & $\begin{array}{l}\text { Obesity } \\
(\boldsymbol{N = 1 7})\end{array}$ & $\begin{array}{l}p \text { value } \\
\text { NA }\end{array}$ \\
\hline As $\left(\mathrm{ng} \mathrm{mL} \mathrm{mL}^{-1}\right)$ & $1.08(0.33-1.88)$ & $1.50(1.01-3.18)$ & $2.75(2.06-3.55)$ & $<0.001^{*}$ \\
$\mathrm{Cd}\left(\mathrm{ng} \mathrm{mL} \mathrm{mL}^{-1}\right)$ & $0.78(0.30-1.95)$ & $1.06(0.84-1.65)$ & $0.94(0.75-2.39)$ & 0.166 \\
$\mathrm{Hg}\left(\mathrm{ng} \mathrm{mL}^{-1}\right)$ & $0.97(0.93-1.02)$ & $0.96(0.93-1.04)$ & $0.95(0.92-1.01)$ & 0.803 \\
\hline
\end{tabular}

Data are expressed medians (interquartile rank). The Kruskal-Wallis test was used to compare continuous variables. *Significant $p$ values $(p<0.05)$. Abbreviations: $A s$, arsenic; $C d$, cadmium; $H g$, mercury
Table 3 Association of serum As, Cd, and Hg levels with BMI and FPG

\begin{tabular}{llll}
\hline Element & Trait & Unadjusted\# & Adjusted for age and sex\#\# \\
\hline As $\left(\mathrm{ng} \mathrm{mL} \mathrm{mL}^{-1}\right)$ & BMI & $0.489(<0.001)^{*}$ & $0.446(<0.001)^{*}$ \\
& FPG & $0.237(0.030)^{*}$ & $0.282(0.012)^{*}$ \\
$\mathrm{Cd}\left(\mathrm{ng} \mathrm{mL}{ }^{-1}\right)$ & BMI & $0.180(0.105)$ & $0.119(0.296)$ \\
& FPG & $0.079(0.480)$ & $0.031(0.789)$ \\
$\mathrm{Hg}(\mathrm{ng} \mathrm{mL}$ & BMI & $-0.032(0.771)$ & $0.091(0.428)$ \\
& FPG & $0.185(0.087)$ & $0.154(0.176)$ \\
\hline
\end{tabular}

Data are expressed Spearman's rank correlation coefficient ( $p$ value). \#Unadjusted Spearman's correlations; \#\#Spearman's rank correlation analysis adjusted for age, and age and sex. *Significant $p$ values $(p<0.05)$. Abbreviations: $B M I$, body mass index; $F P G$, fasting plasma glucose; $A s$, arsenic; $C d$, cadmium; $H g$, mercury

\section{Discussion}

The results from this study allowed us to determine the associations between serum $\mathrm{As}, \mathrm{Cd}$, and $\mathrm{Hg}$ levels and BMI and FPG in a Mexican adult population. The analyses showed that $\mathrm{Cd}$ and $\mathrm{Hg}$ did not show any significant associations with these parameters, which is in contrast with other studies that reported associations between $\mathrm{Hg}$ or $\mathrm{Cd}$ and obesity [34-39]. The lack of association between $\mathrm{Hg}$ and BMI and FPG could be explained by the use of serum because whole blood has been considered a better biological sample to evaluate $\mathrm{Hg}$ exposure [40]. However, whole blood has been considered a complex sample in comparison with serum. Moreover, exposure to $\mathrm{As}, \mathrm{Cd}$, and $\mathrm{Hg}$ has been reported to be associated with obesity and diabetes mellitus, where they affect glucose homeostasis [34]. While we did not find a significant association between $\mathrm{Cd}$ and $\mathrm{Hg}$ and BMI and FPG, previous studies have reported that $\mathrm{Cd}$ and $\mathrm{Hg}$ exposure increases insulin resistance as a consequence of adiponectin secretion and disrupts pancreatic $\beta$-cells and insulin deactivation [41, 42].

Exposure to As has been attributed to food intake, where its main exposure occurs through drinking water that has high levels of As [43]. It is worth mentioning that As is not considered an obesogenic element. Nevertheless, the results obtained in this study show the existence of a positive association between serum As levels and BMI and FPG. These results are consistent with other previously reported studies on the associations between As and obesity, glucose homeostasis, and diabetes mellitus [15]. Most of these previous studies propose a mechanism that acts through pancreatic oxidative damage, which impairs insulin synthesis and secretion by damaging pancreatic beta-cell functions. Additionally, insulin resistance in skeletal muscle increases gluconeogenesis in the liver and modulates other hepatic insulin signaling pathways [44-47]. However, to date, the full mechanism to explain the associations between As and obesity and diabetes mellitus has been unclear. Animal experimental models have shown that As exposure significantly increased reactive oxygen species and malondialdehyde formation in pancreatic $\beta$-cells, leading to decreased insulin secretion [16]. Other studies have shown that PPAR $\gamma$-mTOR complex 2 (mTORC2) signaling is activated at low concentrations and induces insulin resistance [48]. Thus, it is clear that As plays a significant role in the development of obesity and diabetes mellitus. Nevertheless, future studies are necessary to evaluate the associations between As exposure and genetic factors. Moreover, some variants in specific genes could represent a risk of developing impaired metabolic pathways that could exacerbate the metabolic effects of any toxic element exposure $[49,50]$.

It is generally recognized that a sedentary lifestyle with high caloric food intake is crucial in the development of obesity and related metabolic complications. Nevertheless, our results show for the first time a significant association between serum As levels and BMI and FPG in a Mexican population, which is relevant due to a lack of epidemiological studies in this country. Thus, it is important to replicate our results and perform more epidemiologic and genetics studies to accumulate enough evidence to contribute to understanding the relationship between As and obesity and markers of glucose metabolism in the Mexican population.

One limitation of this study is the small sample size that was analyzed. Additionally, we recognize that the inclusion of data regarding demographic characteristics of the population and food and water intake could increase the relevance of our results. Moreover, in the case of exposure to $\mathrm{Hg}$ and $\mathrm{Cd}$, it is important to consider smoking habits [51] and fish 
and shellfish intake because they contain elevated levels of methylmercury in their tissues [52]. Finally, our study did not include body fat percentage in the analysis, which could improve the analysis of the associations between $\mathrm{As}, \mathrm{Cd}$, and $\mathrm{Hg}$ levels and body fat.

\section{Conclusion}

This study reveals a significant positive association between serum As levels and BMI and FPG in a Mexican adult population. Nevertheless, a significant association between serum $\mathrm{Cd}$ and $\mathrm{Hg}$ levels and BMI or FPG was not demonstrated. The epidemiologic and genetic studies related to toxic elements and metabolic diseases could strengthen our evidence.

Funding We acknowledge the funding granted by Consejo Nacional de Ciencia y Tecnología (CONACYT) in the following projects: Laboratorio Nacional de Ciencia, Tecnología y Gestión Integrada del Agua (299030).

Availability of Data and Material The dataset of this study is available from the corresponding authors on reasonable request.

\section{Declarations}

Conflict of Interest The authors declare no competing interests.

\section{References}

1. GBD (2015) Obesity Collaborators (2017) Health effects of overweight and obesity in 195 countries over 25 years. Engl J Med. https://doi.org/10.1056/NEJMoa1614362

2. NCD Risk Factor Collaboration (NCD-RisC) (2017) Worldwide trends in body-mass index, underweight, overweight, and obesity from 1975 to 2016: a pooled analysis of 2416 population-based measurement studies in 128.9 million children, adolescents, and adults. Lancet 390:2627-2642. http://dx.doi.org/https://doi.org/10. 1016/S0140-6736(17)32129-3

3. WHO. Obesity and overweight (2021) https://www.who.int/newsroom/fact-sheets/detail/obesity-and-overweight. Accessed 5 October 2021

4. Saltiel AR, Olefsky JM (2017) Inflammatory mechanisms linking obesity and metabolic disease. J Clin Investig 127(1):1-4. https:// doi.org/10.1172/JCI92035

5. Chait A, den Hartigh LJ (2020) Adipose tissue distribution, inflammation and its metabolic consequences, including diabetes and cardiovascular disease. Front Cardiovasc Med 7:22. https:// doi.org/10.3389/fcvm.2020.00022

6. Furukawa S, Fujita T, Shimabukuro M, Iwaki M, Yamada Y, Nakajima Y, Nakayama O, Makishima M, Matsuda M, Shimomura I (2017) Increased oxidative stress in obesity and its impact on metabolic syndrome. J Clin Invest 114(12):1752-1761. https://doi.org/10.1172/JCI21625

7. Low FM, Gluckman PD, Hanson MA (2021) Chapter 14: Epigenetic and developmental basis of risk of obesity and metabolic disease. Cellular Endocrinology in Health and Disease
(Second Edition). Academic Press 289-313. https://doi.org/10. 1016/B978-0-12-819801-8.00014-4

8. Karlsson T, Rask-Andersen M, Pan G, Höglund J, Wadelius C, Ek WE, Johansson $\AA$ (2019) Contribution of genetics to visceral adiposity and its relation to cardiovascular and metabolic disease. Nat Med 25:1390-1395. https://doi.org/10.1038/ s41591-019-0563-7

9. Cornejo-Pareja IM, Gómez-Pérez AM, Fernández-García JC, Barahona San Millan R, Aguilera Luque A, de Hollanda A, Jiménez A, Jimenez-Murcia S, Munguia L, Fernandez-Aranda OE, F, Fernández Real JM, Tinahones F, (2020) Coronavirus disease 2019 (COVID-19) and obesity. Impact of obesity and its main comorbidities in the evolution of the disease. Eur Eat Disord Rev 28:799-815. https://doi.org/10.1002/erv.2770

10. Klang E, Kassim G, Soffer S, Freeman R, Levin MA, Reich DL (2020) Severe obesity as an independent risk factor for COVID19 mortality in hospitalized patients younger than 50 . Obes 28(9):1595-1599. https://doi.org/10.1002/oby.22913

11. Eastment MC, Berry K, Locke E, Green P, O'Hare A, Crothers K, Dominitz JA, Fan VS, Shah JV, Ioannou GI (2021) BMI and outcomes of SARS-CoV-2 among US veterans. Obes 29(5):900-908. https://doi.org/10.1002/oby.23111

12. Rivera JÁ, de Cossío TG, Pedraza LS, Aburto TC, Sánchez TG, Martorell R (2014) Childhood and adolescent overweight and obesity in Latin America: a systematic review. Lancet Diabetes Endocrin 2(4):321-332. https://doi.org/10.1016/S2213-8587(13) 70173-6

13. OCED (2017) Obesity update 2017. https://www.oecd.org/health/ health-systems/Obesity-Update-2017.pdf. Accessed October 2021

14. WHO (2020) 10 chemicals of public health concern. https://www. who.int/news-room/photo-story/photo-story-detail/10-chemicalsof-public-health-concern. Accessed October 202.

15. Castriota F, Acevedo J, Ferreccio C, Smith AH, Liaw J, Smith MT, Steinmaus C (2018) Obesity and increased susceptibility to arsenic-related type 2 diabetes in Northern Chile. Environ Res 167:248-254. https://doi.org/10.1016/j.envres.2018.07.022

16. Farkhondeh T, Samarghandian S, Azimi-Nezhad M (2019) The role of arsenic in obesity and diabetes. J Cell Physiol 234(8):12516-12529. https://doi.org/10.1002/jcp.28112

17. Tinkov AA, Filippini T, Ajsuvakova OP, Aaseth J, Gluhcheva YG, Ivanova JM, Bjørklund G, Skalnaya MG, Gatiatulina ER, Popova EV, Nemereshina ON, Vinceti M, Skalny AV (2017) The role of cadmium in obesity and diabetes. Sci Total Environ 601-602:741755. https://doi.org/10.1016/j.scitotenv.2017.05.224

18. Jeon J, Morris JS, Park K (2021) Toenail mercury levels positively correlate with obesity and abdominal obesity among Korean adults. J Trace Elem Med Biol 64:126678. https://doi.org/10. 1016/j.jtemb.2020.126678

19. Su CT, Lin HC, Choy CS, Huang YK, Huang SR, Hsueh YM (2012) The relationship between obesity, insulin and arsenic methylation capability in Taiwan adolescents. Sci Total Environ 414:152-158. https://doi.org/10.1016/j.scitotenv.2011.10.023

20. Tinkov AA, Ajsuvakova OP, Skalnaya MG, Popova EV, Sinitskii AI, Nemereshina ON, Gatiatulina ER, Nikonorov AA, Skalny AV (2015) Mercury and metabolic syndrome: a review of experimental and clinical observations. Biometals 28(2):231-254. https:// doi.org/10.1007/s 10534-015-9823-2

21. Jomova K, Jenisova Z, Feszterova M, Baros S, Liska J, Hudecova D, Rhodes CJ, Valko M (2011) Arsenic: toxicity, oxidative stress and human disease. J Appl Toxicol 31(2):95-107. https://doi.org/ 10.1002/jat.1649

22. Renu K, Madhyastha H, Madhyastha R, Maruyama M, Arunachlam S, Abilash VG (2018) Role of arsenic exposure in adipose tissue dysfunction and its possible implication in diabetes pathophysiology. Toxicol Lett 284:86-95. https://doi.org/10.1016/j. toxlet.2017.11.032 
23. Attia SM, Varadharajan K, Shanmugakonar M, Das SC, Al-Naemi HA (2021) Cadmium: an emerging role in adipose tissue dysfunction. Expo Health. https://doi.org/10.1007/s12403-021-00427-3

24. Filippini T, Wise L, Vinceti M (2022) Cadmium exposure and risk of diabetes and prediabetes: a systematic review and doseresponse meta-analysis. Environ Int 158:106920. https://doi.org/ 10.1016/j.envint.2021.106920

25. Stratakis N, Conti DV, Borras E, Sabido E, Roumeliotaki T, Papadopoulou E, Agier L, Basagana X, Bustamante M, Casas M, Farzan SF, Fossati S, Gonzalez JR, Grazuleviciene R, Heude B, Maitre L, McEachan RC, Theologidis I, Urquiza J, Vafeiadi M, Jane W, Wright J, McConnell R, Brantsaeter A-L, Meltzer H-M, Vrijheid M, Chatzi L (2020) Association of fish consumption and mercury exposure during pregnancy with metabolic health and inflammatory biomarkers in children. JAMA Netw Open 3(3):e201007. https://doi.org/10.1001/jamanetworkopen.2020. 1007

26. Tinkov AA, Aschner M, Ke T, Ferrer B, Zhou JC, Chang JS, Santamaría A, Chao JC-J, Aaseth J, Skalny AV (2021) Adipotropic effects of heavy metals and their potential role in obesity. Faculty Reviews 10:(32). https://doi.org/10.12703/r/10-32

27. Lee S, Cho SR, Jeong I, Park JB, Shin MY, Kim S, Kim JH (2020) Mercury exposure and associations with hyperlipidemia and elevated liver enzymes: a nationwide cross-sectional survey. Toxics 8(3):47. https://doi.org/10.3390/toxics8030047

28. Rotter I, Kosik-Bogacka D, Dołęgowska B, Safranow K, Lubkowska A, Laszczyńska M (2015) Relationship between the concentrations of heavy metals and bioelements in aging men with metabolic syndrome. Int J Environ Res Public Health 12(4):39443961. https://doi.org/10.3390/ijerph120403944

29. Rosella LC, Lebenbaum M, Fitzpatrick T, Zuk A, Booth GL (2015) Prevalence of prediabetes and undiagnosed diabetes in Canada (2007-2011) according to fasting plasma glucose and HbA1c screening criteria. Diabetes Care 38(7):1299-1305. https://doi.org/10.2337/dc14-2474

30. NCD Risk Factor Collaboration (NCD-RisC) - Africa Working Group (2017) Trends in obesity and diabetes across Africa from 1980 to 2014: an analysis of pooled population-based studies. Int J Epidemiol 46(5):1421-1432. https://doi.org/10.1093/ije/dyx078

31. Planchart A, Green A, Hoyo C, Mattingly CJ (2018) Heavy metal exposure and metabolic syndrome: evidence from human and model system studies. Curr Envir Health Rpt 5(1):110-124. https://doi.org/10.1007/s40572-018-0182-3

32. American Diabetes Association (2004) Diagnosis and classification of diabetes mellitus. Diabetes Care 27(suppl 1):s5-s10. https://doi.org/10.2337/diacare.27.2007.S5

33. Vázquez-Moreno M, Mejía-Benítez A, Sharma T, Peralta-Romero J, Locia-Morales D, Klünder-Klünder M, Mexico NON, Cruz M, Meyre D (2020) Association of AMY1A/AMY2A copy numbers and AMY1/AMY2 serum enzymatic activity with obesity in Mexican children. Pediatric Obes 15(8):e12641. https://doi.org/ 10.1111/ijpo.12641

34. Moon MK, Lee I, Lee A, Park H, Kim MJ, Kim S, Cho YL, Hong S, Yoo J, Cheon GJ, Choi K, Park YJ, Park J (2022) Lead, mercury, and cadmium exposures are associated with obesity but not with diabetes mellitus: Korean National Environmental Health Survey (KoNEHS) 2015-2017. Environ Res 204(Pt A):111888. https://doi.org/10.1016/j.envres.2021.111888

35. Lee K (2018) Blood mercury concentration in relation to metabolic and weight phenotypes using the KNHANES 2011-2013 data. Int Arch Occup Environ Health 91:185-193. https://doi.org/ 10.1007/s00420-017-1269-0

36. Lee B-K, Kim Y (2016) Association of blood cadmium level with metabolic syndrome after adjustment for confounding by serum ferritin and other factors: 2008-2012 Korean National Health and
Nutrition Examination Survey. Biol Trace Elem Res 171:6-16. https://doi.org/10.1007/s12011-015-0499-9

37. Park JS, Ha KH, He K, Kim DJ (2017) Association between blood mercury level and visceral adiposity in adults. Diabetes Metab J 41(2):113-120. https://doi.org/10.4093/dmj.2017.41.2.113

38. Rothenberg SE, Korrick SA, Fayad R (2015) The influence of obesity on blood mercury levels for U.S. non-pregnant adults and children: NHANES 2007-2010. Environ Res 138:173-180. https://doi.org/10.1016/j.envres.2015.01.018

39. Wang X, Mukherjee B, Park SK (2018) Associations of cumulative exposure to heavy metal mixtures with obesity and its comorbidities among U.S. adults in NHANES 2003-2014. Environ Int 121(Part 1):683-694. https://doi.org/10.1016/j.envint.2018.09.035

40. Moon MK, Lee I, Lee A, Park H, Kim MJ, Kim S, Cho YH, Hong S, Yoo J, Cheon GJ, Choi K, Park YJ, Park J (2022) Lead, mercury, and cadmium exposures are associated with obesity but not with diabetes mellitus: Korean National Environmental Health Survey (KoNEHS) 2015-2017. Environ Res 204(Part A):111888. https://doi.org/10.1016/j.envres.2021.111888

41. Sargis RM (2014) The hijacking of cellular signaling and the diabetes epidemic: mechanisms of environmental disruption of insulin action and glucose homeostasis. Diabetes Metab J 38:13-24. https://doi.org/10.4093/dmj.2014.38.1.13

42. Kuo C-C, Moon K, Thayer KA, Navas-Acien A (2013) Environmental chemicals and type 2 diabetes: an updated systematic review of the epidemiologic evidence. Curr Diab Rep 13(6):831849. https://doi.org/10.1007/s11892-013-0432-6

43. Fu Z, Xi S (2020) The effects of heavy metals on human metabolism. Toxicol Mech Methods 30(3):167-176. https://doi.org/10. 1080/15376516.2019.1701594

44. Ceja-Galicia ZA, Daniel A, Salazar AM, Pánico P, OstroskyWegman P, Díaz-Villaseñor A (2017) Effects of arsenic on adipocyte metabolism: is arsenic an obesogen? Mol Cell Endocrinol 452(5):25-32. https://doi.org/10.1016/j.mce.2017.05.008

45. Díaz-Villaseñor A, Sánchez-Soto MC, Cebrián ME, OstroskyWegman P, Hiriart M (2006) Sodium arsenite impairs insulin secretion and transcription in pancreatic beta-cells. Toxicol Appl Pharmacol 214(1):30-34. https://doi.org/10.1016/j.taap.2005.11. 015

46. Hamann I, Petroll K, Hou X, Anwar-Mohamed A, El-Kadi AOS, Klotz L-O (2014) Acute and long-term effects of arsenite in HepG2 cells: modulation of insulin signaling. Biometals 27:317-332. https://doi.org/10.1007/s10534-014-9714-y

47. Divya SP, Pratheeshkumar P, Son Y-O, Roy RV, Hitron JA, Kim D, Dai J, Wang L, Asha P, Huang B, Xu M, Luo J, Zhang Z (2015) Arsenic induces insulin resistance in mouse adipocytes and myotubes via oxidative stress-regulated mitochondrial Sirt3-FOXO3a signaling pathway. Toxicol Sci 146(2):290-300. https://doi.org/ 10.1093/toxsci/kfv089

48. Gao N, Yao X, Jiang L, Yang L, Qiu T, Wang Z, Pei P, Yang G, Liu X, Sun X (2018) Taurine improves low-level inorganic arsenic-induced insulin resistance by activating PPAR $\gamma$-mTORC2 signalling and inhibiting hepatic autophagy. J Cell Physiol 234(4):5143-5152. https://doi.org/10.1002/jcp.27318

49. Sasaki A, Matthews SG (2019) Genome-wide epigenetic signatures of childhood adversity in early life: opportunities and challenges. J Dev Orig Health Dis 10(1):65-72. https://doi.org/10. 1017/S2040174418000843

50. Zhang Y (2017) Trace elements and healthcare: a bioinformatics perspective. In: Shen B. (eds) Translational informatics in smart healthcare. Adv Exp Med Biol 1005:63-98

51. Dinh QP, Novirsa R, Jeong H, Nugraha WC, Addai-Arhin S, Viet PH, Tominaga N, Ishibashi Y, Arizono K (2021) Mercury, cadmium, and lead in cigarettes from international markets: 
concentrations, distributions and absorption ability of filters. J Toxicol Sci 46(9):401-411. https://doi.org/10.2131/jts.46.40

52. Bjermo H, Sand S, Nälsén C, Lundh T, Barbieri HE, Pearson M, Lindroos AK, Jönsson BAG, Barregård L, Darnerud PO (2013) Lead, mercury, and cadmium in blood and their relation to diet among Swedish adults. Food Chem Toxicol 57:161-169. https:// doi.org/10.1016/j.fct.2013.03.024
Publisher's Note Springer Nature remains neutral with regard to jurisdictional claims in published maps and institutional affiliations. 